\title{
Stand dynamics of an oak woodland forest and effects of a restoration
}

\section{treatment on forest health}

Stacy L. Clark ${ }^{1}$ and Callie J. Schweitzer ${ }^{2}$

${ }^{1}$ Corresponding author; Research Forester, USDA Forest Service, Southern Research Station, 2431 Joe Johnson Drive, Knoxville, TN USA; 1+ 865-974-0932; stacyclark@fs.fed.us

${ }^{2}$ Supervisory Research Forester, USDA Forest Service, Southern Research Station, Huntsville, AL USA; cschweitzer@fs.fed.us

\begin{abstract}
Woodland restoration has been conducted in many countries, primarily in Mediterranean regions, but has only recently been attempted on publically and privately owned lands in the eastern United States. We reconstructed historical stand dynamics and tested the immediate effects of an oak (Quercus) woodland restoration treatment on forest health, inferred from tree-ring widths (TRW). The stands were upland white oak (Q. $a l b a)$ and chestnut oak ( $Q$. prinus) dominated and were located on the Cumberland Plateau of eastern Kentucky, USA. The stands regenerated primarily under a severe disturbance regime concurrent with peak industrial logging approximately 100 years ago. A relatively high percentage of trees (38 percent) recruited under large canopy gaps or clearings, indicative of a severe disturbance; however, gap-phase dynamics was also an important process in oak recruitment to the canopy. Primarily small $(<31 \mathrm{~cm} \mathrm{DBH})$ and young $(<110$ years old) trees were removed during the restoration treatment, and mean $\mathrm{DBH}$ of residual trees was $13 \mathrm{~cm}$ larger than harvested trees. Residual trees were 22 years older than harvested trees, but this difference was not significant. The largest and oldest trees were retained and they represented important legacy trees that
\end{abstract}


could provide desirable forest biodiversity attributes. Residual trees had larger TRWs than harvested trees, beginning in the 1930s, and these differences increased over time. Residual trees also had larger TRW during two recent drought events (1986 and 1999), but recovery following drought was similar between residual and harvested trees. Managers can use well established silvicultural techniques to obtain desired stand structural conditions, while selecting healthy trees that have better response to stress factors such as drought. The restoration treatment may help to maintain residual overstory trees until oak regeneration can be recruited to provide sustainability towards the next generation.

\section{Introduction}

Forest restoration is a management goal for many public and private forest land owners throughout the world where long-term sustainability and resiliency are important targets (Stanturf, 2015). Restoration has been an evolving concept in which terminology and goals are sometimes debated, but it is generally agreed that forest restoration requires the implementation of silvicultural practices (Dumroese et al., 2015; Stanturf, 2015). Restored oak woodlands is a desired future condition in many southeastern forests of the U.S., with specific restoration goals and objectives included in Land and Resource Management Plans for national forests of the USDA Forest Service (USDA Forest Service, 2004a, 2004b, 2004c), for management coalitions involving Non-governmental Organizations (NGOs) such as the Nature Conservancy (USDA Forest Service, 2015), and for state agencies (Vander Yact, 2013).

A woodland has been defined as having attributes of an oak dominated overstory, a sparse midstory and understory, and diverse ground flora (Dey et al. 2016). Open-structured oak woodlands were historically important throughout the world, particularly in Mediterranean 
climates (Roche et al., 2012; Selvi and Valleri, 2012; Schaich et al., 2015), but were also widespread in the temperate zone of the Midwest and Central Hardwood Region of the United States (Fralish et al., 2000; Dey et al., 2016). Oak woodlands in the US have been reduced in extent since European settlement, and fire was an important historical process in these ecosystems (Ryan et al., 2013). Fire alone will typically not restore open woodlands, however, if overstory tree density is relatively high (Arthur et al., 2015; Brose, 2014). The oak woodlands of the southern Appalachian region probably occurred on sites with specific edaphic qualities that limited available soil moisture, such as shallow, rocky soils, but the historical spatial and temporal extent of oak woodlands in the region is relatively unknown (Matlack, 2013).

Tree-ring analysis (i.e., dendrochronology) is a robust tool that can be used to understand current forest conditions, causes of degradation, and in development of realistic end points or targets for restoration. Dendrochronology augmented by field measurements can be used to test for desirable indicators of restoration, including a diverse stand age and size structure, tree growth, and diverse species composition (Hart et al., 2012; Anning et al., 2014; Haavick et al., 2015; Pach and Podlaski, 2015). Tree-ring growth rates can be used to infer overall forest health conditions because they correlate well to survival following stress events, such as drought or insect attacks (Pederson, 1998; Voelker et al. 2008; Haavik et al. 2015).

Silviculture, applied through commercial timber harvesting, can provide a cost-efficient and ecologically effective way to initiate the process of restoring oak woodland habitat by reducing stand density while retaining healthy oak trees (Dey, 2014). However, management effects of restoration treatments on desired ecological conditions, such as improved forest health, have gone relatively untested. While thinning or other silvicultural practices improve 
tree growth for timber (Gingrich 1970), these same practices can be applied to meet restoration goals, such as improving resiliency or adaptability to impending threats such as insect attacks, drought, or climate change (Dumroese et al., 2015).

A landscape-scale (approximately 1300 ha) study was implemented in eastern Kentucky, USA in 2004, under the auspices of the 2003 Healthy Forest Restoration Act, as part of the Daniel Boone National Forest Management Plan (USDA Forest Service, 2004a). The study was designed to examine how various silvicultural treatments may enhance resiliency of oak dominated forests to impending forest health concerns, including oak decline and threats from exotic invasive pests (Schweitzer et al., 2014). One of the silvicultural treatments in this study included restoration of putatively degraded closed-canopy forests to open oak woodland habitat using commercial timber harvest followed by prescribed fire. Early field data indicated that the initiation (i.e., commercial timber harvest) of the woodland restoration treatment increased oak dominance and crown vigor, but questions remain about the health and potential resiliency of residual trees once prescribed burn treatments are implemented.

In this study, we reconstructed stand history and examined effects on forest structure and tree health due to an oak woodland restoration treatment using the dominant canopy species, white oak (Q. alba L.) and chestnut oak (Q. prinus L.). This forest has not yet been impacted by exotic insects, but other disturbances that affect forest health have occurred, including drought. The objectives of our study were to 1) reconstruct historical temporal dynamics of white oak species using dendrochronology to better understand forest development and conditions prior to the restoration treatment, and, 2) to determine the immediate impact of the oak woodland restoration treatment on indicators of forest resiliency 
and adaptability. For objective two, we compared and contrasted harvested and residual trees for differences in a) age and size structural attributes, and b) health inferred from past tree-ring growth.

\section{Methods}

\subsection{Study site}

The study took place on the Daniel Boone National Forest, London Ranger District, Kentucky, and the oak woodland restoration treatment was replicated in 6, 10 ha stands throughout the forest as previously described in Schweitzer and others (2014). The oak woodland restoration treatment was initiated in 2007 by commercially harvesting 40 to 60 percent of trees $\geq 13 \mathrm{~cm}$ diameter at breast height $(\mathrm{DBH})$ to obtain a residual basal area of $10-$ $16 \mathrm{~m}^{2} \mathrm{ha}^{-1}$. Non-commercial trees $<13 \mathrm{~cm} \mathrm{DBH}$ were felled using chainsaws. White oak and chestnut oaks were favored as residual trees, and an objective of the treatment was spatial and vertical heterogeneity. The harvesting treatment was to be followed by prescribed burning every three years beginning in 2010. We randomly selected 5 of the original 20 circular vegetation plots (0.01 ha) described in Schweitzer and others (2014) from each stand to conduct our data collection.

\subsection{Data collection}

Prior to restoration treatment in winter 2005, we measured diameter at breast height $(D B H)$ of all white oak $(n=71)$ and chestnut oak $(n=65) \geq 13 \mathrm{~cm}$ DBH on each plot in each stand. Each tree was permanently tagged. Cores were collected from each tree using increment borers at breast height $(\sim 1.4 \mathrm{~m})$ prior to treatment. Only one core per tree was collected. One year after woodland restoration treatments were implemented (2008), but prior to the first 
prescribed burn, we tallied residual and cut trees. Tree cores were not collected following the treatment.

We processed (i.e., mounted and sanded) cores using standard techniques (Stokes and Smiley, 1996), and visually dated each core under a stereo-zoom microscope. We measured annual tree-ring widths (TRW) to the nearest $0.001 \mathrm{~mm}$ using a Velmex stage micrometer and MeasureJ2X software. We used COFECHA software for quality control of dating to ensure each ring was dating to the exact calendar year (Grissino-Mayer, 2001). If the pith was not visible, we used graphical techniques to estimate the pith date (Clark and Hallgren, 2004). If visible estimation of the pith was not possible, we used linear regression to predict age from DBH using SAS software (SAS, 2012) (Clark and Hallgren, 2004).

\subsection{Release chronology development}

We excluded 33 cores from tree-ring analysis due to rot, damage, or exceptionally suppressed growth that made tree-ring measurements impractical, for a total of 59 white oak cores and 44 chestnut oak cores used in this study. We identified canopy releases across both species using the radial growth averaging technique, a proven method to detect canopy disturbances in oak species (Nowacki and Abrams, 1997; Rentch et al., 2002). A previous study found a 1:1 relationship between canopy release and percent growth change in ring-width in 55 year old trees (Rentch et al., 2002). We identified a release when the percent growth change between the running mean of the previous and the subsequent 10 years in TRW exceeded a certain threshold, but older trees have been found to be less sensitive to release detection (Nowacki and Abrams, 1997; McEwan et al., 2014). Therefore, we lowered the threshold for release detection based on examination of linear regression equations to predict positive 
percent growth change by age. Although positive percent growth change was not well explained by age, the relationship was statistically significant $\left(R^{2}=0.01, P<0.0001\right)$,

$$
\mathrm{y}=35.70-0.21 \times\left(0.00001 \times A g e^{3}\right)
$$

We used the maximum predicted value for young trees (1-100 years old), and older trees in 50 year age classes to set our lower threshold for detecting minor release events (Table 1). Major release events were identified as releases with twice the value of the minimum threshold value (Nowacki and Abrams 1997). Our threshold values for the younger age classes, which represented the majority of trees we sampled, were slightly higher than thresholds used in other studies (Rentch et al., 2002; Hart et al., 2012; McEwan et al., 2014) that were based in old-growth forests where older trees have more conservative responses to disturbances (Nowacki and Abrams, 1997). The lower threshold values for older trees is supported by previous research showing that reduced growth response is reduced by age (Nowacki and Abrams, 1997; McEwan et al., 2014), but older trees were rare in this study (Table 1). We identified releases when the release threshold was sustained for 3 or more consecutive years, a relatively conservative approach in detection of release events that helps to rule out falsepositive events (Hart and Grissino-Mayer, 2008; Hart et al., 2012).

Release response duration could sometimes last a decade or more and include consecutive minor and major release years. Because it is impossible to determine if multiple release events were occurring consecutively, we classified these long duration events as a single release event. We classified releases as 'major' if more than three years during the release duration exceeded the major release threshold. Otherwise, they were classified as minor release events. This was justified because a 1 to 3 year lag occurs between a disturbance 
event and associated maximum release response (Rentch et al., 2002). We classified a largescale release as a release detected in at least one tree in each of the six stands.

A release event was defined as all consecutive years in a single release, and a release initiation year was defined as the first year of a release event. We calculated the return interval (mean, standard deviation, and median) as the number of years between two consecutive releases for release initiations and release events using the composite data from all trees in all stands. We used the Fire History Analysis and Exploration System (FHAES) to graph release chronologies.

\subsection{Classification of recruitment types}

Trees in which the pith was visible and all tree-rings could be measured $(n=58)$ were classified into understory origin or gap origin based on their early radial growth patterns (Rentch et al., 2003; Hart et al., 2012). If the mean of the first 20 years of TRW exceeded the mean of the second 20 years of TRW, the tree was classified as gap origin (GO) tree. Otherwise, the tree was classified as understory origin (UO). If the tree had at least one major release event after the first twenty years with ring-width greater than $1.4 \mathrm{~mm}$ (chronology mean ring width) during the peak of the release, we classified it as gap release (GR). Otherwise, we classified the tree as no release (NR). Therefore, four categories of recruitment were possible, GOGR, GONR, UOGR, or UONR. GONR trees are assumed to have originated from relatively large gaps because they experienced no additional release for their recruitment, while GOGR trees are assumed to have originated from smaller gaps, such as single-tree gaps, because additional releases were required for their overstory recruitment (Rentch et al., 2003) We visually examined each graphically displayed series to confirm recruitment classes according to 
Rentch and others (2003), and we confirmed the trees classified as UONR were not in dominant or co-dominant canopy positions using data from Schweitzer and others (2014).

\subsection{Identification of past drought}

We examined climate data from three local weather stations (USC00154905, USC00154893, USW00003849) and Kentucky Climate Division 04 (NOAA 2015) to identify potential drought years. Station data were only available after 1945, so we restricted our examination of drought after this date. We first examined the Palmer Drought Severity Index (PDSI) monthly data for Kentucky Division 04. PDSI ranges from -4 (extreme drought) to 4 (extreme wet), and it incorporates several environmental factors affecting tree growth including soil water availability (Palmer, 1965). We looked for low early summer (May-July) PDSI values (i.e., below normal) that occurred in two or more consecutive years, and we corroborated these low PDSI values with low summer precipitation values (i.e., below average) from the local weather stations. May through July climate has consistently shown high correlations with oak tree growth (LeBlanc and Terrell 1993). We selected four drought events (Table 2), and the two years following the drought were recovery periods for further empirical tests of the treatments as described below. Drought periods had below average precipitation and PDSI while the recovery periods had average to above average values.

\subsection{Statistical analysis}

A 5 percent alpha level was used to denote statistical significance for all tests. We ignored species as an effect in statistical tests due to relatively low sample sizes. We combined the two species from all six stands to identify release events, develop release chronologies, estimate release statistics, and calculate frequency of recruitment types. Mean, standard 
deviation (SD) and Weibull median release return intervals were calculated for release initiation years using the composite chronology in FHAES. A decadal release index was calculated by dividing the total number of releases across all trees by the maximum number of trees sampled for that decade, which is similar to the release frequency to sample size ratio developed by Buchanan and Hart (2012). The release index is intended to compensate for sample size bias. We calculated the release index for all release events, and for release initiations of major and minor releases.

We calculated mean tree densities (trees ha ${ }^{-1}$ ) across stands before and after the restoration treatment by 10 -year age and 3-cm DBH classes. We used asymptotic KolmogorovSmirnov (KSa) two-sample tests in SAS (SAS 2012; Proc NPAR1WAY) to determine differences in age and diameter distributions before and after the restoration treatment.

We calculated mean TRW for each tree during the four identified droughts (Table 2). We also calculated percent growth change in mean TRW for each tree from the drought to the recovery period:

$$
\% \text { Growth Change }=\left(\frac{\mathrm{TRW}_{r}-\mathrm{TRW}_{d}}{T R W_{d}}\right)
$$

where $\mathrm{TRW}_{d}$ was mean TRW during the drought event and TRW $r$ was the mean TRW during the recovery period.

We tested fixed effects of the restoration treatment on continuous dependent variables age, DBH, mean TRW during drought, and mean percent growth change in TRW during drought using general linear mixed models in SAS (PROC MIXED). We analyzed data for these models as a randomized block design (RBD) where stand $(n=6)$ was the random block effect in all models. The fixed effect of restoration treatment consisted of two levels, denoting if a tree was 
harvested or was left as a residual following the restoration treatment. A separate model (PROC MIXED) was used to test the fixed effects of restoration treatment, decade, and the interaction on yearly TRW. This model was analyzed as a RBD with a split-plot treatment arrangement, where restoration treatment was the whole plot and decade was the sub plot. We used treering data for the common period across stands (after 1900) in this model. We included decade in this model to filter out high frequency yearly variability of TRW while preserving all data from each tree series. Additionally, we wanted to determine broad temporal patterns in TRW response to fixed effects. We used TRW, as opposed to basal area increment (BAI), because we only collected one core per tree, which can bias BAI measurements when the pith is off-center. For models analyzing age, DBH, TRW during drought, and percent growth change in TRW during drought, plot was a random sampling effect. Plot was treated as a random sampling effect and tree was a random sub-sampling effect for the model analyzing yearly TRW and decade.

For analyses testing effects of restoration treatment on TRW and decades, TRW during drought, or percent growth change in TRW during drought we had a sample size of 51 trees that were residuals, and 52 that were harvested. For the age and DBH models, the sample size was 71 for harvested trees and 65 for residual trees.

Because trees become less sensitive to factors affecting tree-ring growth as they age, age was tested as a covariate in models where TRW or percent growth change was the dependent variable. We tested assumptions of including a covariate in the models, which are that independent variables and the covariate were independent of each other, and no interaction exists between independent variables and the covariate. Age was not included in 
the model as a covariate if these assumptions were not met. Age was inverse transformed to meet normality assumptions.

Comparisons among least-squares (LS) means for models were analyzed using Tukey's mean separation, and LS means are reported with their associated standard error. The 'slice' option was used in the LS means statements to test for restoration treatment effects within each level of decade. Normality assumptions of residuals were assumed if Kolmogorov-Smirnov D-statistic was less than 0.05 or the Shapiro-Wilk W-estimate was greater than 0.95 . Specific $p$ values were not used in normality tests because these tests are sensitive to sample size. Unequal variance was added to the model if needed. The dependent variable age was log transformed, and TRW and percent growth change were log transformed in all models to meet normality assumptions.

\section{Results}

\subsection{Temporal stand dynamics}

Of the 58 trees in which we had pith dates, 69 percent showed evidence of recruitment in gaps (GOGR 31 percent, GONR 38 percent) and 31 percent in the understory (UOGR or UONR), based on early growth patterns. Only one tree (2 percent) was classified as UONR. The average number of years from pith to the first release of UOGR trees was 34 (standard deviation=15.9; median=26), and ranged from 21 to 74 years, and all UOGR trees except one experienced only one release. Most (82 percent) of GONR trees established from 1880 to 1920 (Figure 1). Approximately 44 percent of GOGR trees also established during this time, and trees that recruited in the understory (UOGR or UONR) established at relatively evenly spaced 
intervals from 1874 to 1946 . The one UONR tree was 85 years old at the time of coring, and was cut during the restoration treatment.

Releases were common at both the tree and forest scale (Table 3). Release initiations and release years occurred in 26 percent and 63 percent of the 226 years in the chronology, respectively. Release initiations, both major and minor, became more common over time as sample size increased (Figure 2), while release years were common throughout the entire chronology (Figure 3). The first release was recorded in 1808, a minor release, 37 years after the beginning of the chronology (Figure 3).

Seventy-six percent of all trees recorded at least one release event, and trees averaged 1 release in their life (Table 3). Forty-nine and 22 percent of trees recorded 1 and 2 releases, respectively, and only 6 percent of trees recorded 3 or more releases. A release initiation occurred every 3 years somewhere in the forest (Table 3). The longest period without any release initiations was from 1853-1879 (Figure 2). The longest period of consecutive release initiation years occurred from 1970 to 1985 (16 years). The 1973 release initiation was the most widespread, occurring in 4 of 6 stands and in 10 percent of trees.

Three periods of frequent release occurred from the 1820 s to the $1850 \mathrm{~s}$, the 1880 s to the 1900s, and in the 1970s and 1980s, according to the release index (Figure 4). The longest period without a release year during the common interval for all six stands (1921-1996) was from 1921 to 1931. Large-scale releases occurred in 1950, from 1973 to 1976, and from 1978 to 1991. However, in all but the two youngest stands a large-scale release event also occurred from 1907-1908 (Figure 3). The mean return interval for large-scale events could not be calculated for the common interval due to low sample size $(n=3)$, but if the 1907-1908 event 
was included, the mean return interval was 24 years (standard deviation= 19 years; median=20 years) (Table 3).

\subsection{Size and age structure}

Mid-size and large trees (e.g., > $31 \mathrm{~cm} \mathrm{DBH)} \mathrm{had} \mathrm{relatively} \mathrm{low} \mathrm{densities,} \mathrm{and} \mathrm{the} 16$ and $19 \mathrm{~cm}$ DBH classes had the highest densities prior to the restoration treatment (Figure 5). The restoration treatment removed approximately 70 percent of trees $<31 \mathrm{~cm} \mathrm{DBH}$, and retained approximately 77 percent of larger trees. The DBH distribution changed significantly following the restoration treatment $(\mathrm{KSa}=1.54, \mathrm{P}=0.0170)$. Least-squares mean $\mathrm{DBH}$ of residual and harvested trees was 36 and $23 \mathrm{~cm}$, respectively, and this difference was significant $(\mathrm{F}=14.98$, $P=0.0118)$.

The 90 year-old age class had the highest density before and after the restoration treatment, but density in this age class was reduced by 57 percent (Figure 6). Approximately 59 percent of trees in the seven youngest age classes (50 to 110 years old) were removed during the restoration treatment, but all trees greater than 120 years old were retained. Age distributions did not significantly change due to the restoration treatment (KSa=0.8753, $\mathrm{P}=0.4277$ ). Least-squares mean age of residual and harvested trees was 108 and 86, respectively, and this difference was nearing significance $(F=4.52, P=0.0868)$. The oldest tree was a 290 year-old white oak (ca. 1714).

\subsection{Tree health}

\subsubsection{Differences in TRW between harvested and residual trees}

TRW was not affected by the main effect of restoration treatment ( $F=3.91, P=0.1049)$, but was affected by the main effect of decade $(F=10.23, P<0.0001)$. The interaction between 
treatment and decade was a significant effect on TRW $(F=3.58, P=0.0050)$. The covariate, tree age, was a significant predictor of TRW, but was not included in the model due to violation of the assumption of no interaction between age and independent variables. Residual trees had 0.23 to $0.69 \mathrm{~mm}$ larger TRW than harvested trees from the 1930 to the $2000 \mathrm{~s}$, and these differences were significant in the 1940s and from the 1970s through the 2000s. (Figure 7). In the 1900s decade, harvested trees had $0.45 \mathrm{~mm}$ larger TRW than residual trees, but this difference was not significant $(F=2.25, P=0.1367)$.

\subsubsection{Differences in TRW between harvested and residual trees during drought events}

The effect of restoration treatment on mean TRW during drought events was significant for the two most recent drought events, and was nearing significance for the 1969 drought (Table 6). Residual trees were 0.38 and $0.60 \mathrm{~mm}$ larger in mean TRW than harvested trees for the 1986 and the 1999 droughts, respectively. Percent growth change in TRW following drought events was not affected by the restoration treatment for any of the drought events, separately or combined. Least-squares means for TRW during drought years for residual and harvested trees were 1.21 and $0.88 \mathrm{~mm}$, respectively for all droughts combined, and this difference was bordering on significance. Tree age was only significant as a covariate in the combined model for mean TRW during drought events, and age was positively related to TRW.

\section{Discussion}

\subsection{Historical reconstruction of pre-treatment forest}

Few empirical studies have actually been conducted in second-growth forests (cf. Nowacki et al., 1990; Rentch et al., 2002; Hutchinson et al., 2008), particularly in the southern Appalachian region (cf. Keever, 1953; Hart and Grissino-Mayer, 2008; Hart et al., 2010). Instead, 
most studies that correlate disturbances to species composition changes have been conducted in old-growth forests that represent only a small fraction of existing stands and have been largely immune to severe anthropogenic disturbances that dominated most of the landscape in the $19^{\text {th }}$ and early $20^{\text {th }}$ century (Nowacki and Abrams, 1997; Rentch et al., 2003; McEwan et al., 2014). Peak logging activity in the southeastern United States occurred in the early 1900s, with 913 million board feet harvested in Kentucky in 1907 (Ahern, 1933). Several lines of evidence indicate that the severe disturbance regime ca. 1880 to 1920 created oak-dominated forests in our study, including the large pulse of oak establishment in the 90 year-old age class (Figure 6), a relatively high release index from the 1800 s to the 1920 s (Figure 4), and the large-scale release (if stands with common intervals pre-1910 were analyzed) from 1907 to 1908 . The majority of trees (60 percent) had releases each year from 1900 to $1903(n=7)$, and nearly all of the GONR trees, obtained canopy status from 1880 to 1920 (Figure 1). Obtaining canopy accession directly from the seedling stage ( 1.3 $\mathrm{m}$ in height, coring height), except on the most xeric sites, would require a relatively severe disturbance or several disturbances in close succession (Loftis 1990; Hutchinson et al., 2008; Arthur et al., 2012).

Disturbance events ca. 1880 to 1920 that were intense enough to create distinct age cohorts were found in nearby second-growth (Hart and Grissino-Mayer, 2008) and old-growth Cumberland Plateau forests (McEwan et al., 2014), as well as other forests throughout the eastern United States (Buchanan and Hart, 2012). However, compared to second-growth (Hart and Grissino-Mayer, 2008; McEwan and McCarthy, 2008), and old-growth oak studies (Buchanan and Hart, 2012; Hart et al., 2012) that used similar methodology for release identification, release durations were approximately 5 to 6 years longer in our study, but return 
intervals for release initiations were similar. The majority of these studies, in addition to a study from a nearby old-growth forest that had more conservative criteria than our study (McEwan et al., 2014), had either no releases or were 16 to $>100$ years longer in return intervals for largescale (or widespread) release events following European-settlement compared to our study (24 years). These results provide evidence that releases were more widespread and more intense in our study compared to most others. This finding is compelling because we probably underestimated disturbance frequency because we only used one core per tree (Buchanan and Hart, 2011), and our threshold value for release detection was slightly higher compared to most. The 1950 and 1970s through 1980s large-scale release events in our study could have been caused by logging, spurred by high timber demands during these periods (McKeever and Hatfield, 1984), but we were not successful in obtaining historical logging data for the forest. Concurrent recruitment pulses during these periods were not detected because trees were probably too small (i.e., $<13 \mathrm{~cm} \mathrm{DBH}$ ) to be sampled. Interestingly, relatively high disturbance pulses in the 1980s were also documented in a nearby oak forest (Hart and Grissino-Mayer, 2008), but causes of the releases were unknown.

We had 36 percent more trees recruiting as GONR trees compared to Hart and others (2012), but the percent of trees recruiting in the understory (UOGR; 31 percent) was relatively similar. The difference in number of GONR trees is probably due to the severe disturbance of our forest compared to the old-growth forest of Hart and others (2012) that was characterized by gap-phase dynamics. However, we found 19 percent fewer GONR trees and relatively similar understory recruitment compared to some old-growth forests on the Alleghany Plateau (Rentch et al., 2003), that appeared to establish during stand-initiating disturbances that pre-dated 
European settlement. In our study, understory residence times were similar to Hart and others (2012), but approximately 50 years shorter than Rentch and others (2003). Regardless, results from all studies indicate that white oak species are capable of long understory residence times (30 to $>100$ years) (Abrams, 1996).

Because we cored at breast height $(\sim 1.3 \mathrm{~m})$, trees could be classified as 'advanced reproduction' at their pith date (e.g., Loftis, 1990), and an average of three decades passed until opportune conditions occurred for advance reproduction UOGR trees to recruit to the canopy. Our results support silvicultural practices based on theories that white oak species require a series of disturbances to recruit to the canopy, and that gap-phase dynamics can be an important part of natural stand dynamics in these ecosystems (Hart et al., 2012; McEwan et al., 2014). Field studies have also found empirical support for management using a series of disturbances, including fire, herbicide, and overstory removal, to favor oak recruitment to the canopy, at least to the early stem exclusion stage of forest development (Brose, 2014; Royse et al., 2010; Hutchinson et al., 2012).

\subsection{Changes in forest attributes due to restoration treatment}

Our historical reconstruction coupled with field data indicate that the stands were impacted by exploitive harvesting and conversion to simpler stand structure, which have been viewed as degradation agents that negatively affect forest sustainability (Stanturf et al., 2014a). These severe disturbances, however, led to the creation of an oak dominated forest, the forest type that many public and private land managers are currently attempting to sustain or restore, mostly without success (McEwan et al. 2011). Lack of advanced oak reproduction was 
previously recorded in this forest (Schweitzer et al., 2014), which is also an indicator of forest degradation (Stanturf, 2015).

Three lines of evidence indicate that the restoration treatment improved overall health and vigor of the forest. First, the restoration treatment favored a stand structure that contained larger and older trees. The restoration treatment did not affect age as much as size, which would be expected given that selections were made based on phenotypic characteristics and age is not always closely associated with size in second-growth forests. The increased size, and to a lesser extent, age, of residual trees was a desirable outcome for this restoration treatment, and may be an indicator for improved biodiversity (McElhinny et al. 2005). In particular, the few remnant old trees (e.g., $>200$ years old) that were retained represented important ecological legacies that provided complexity of structure (Stanturf et al., 2014b) and can offer resilience to stressors such as a changing climate (Noss, 2001). Although relationships between stress resiliency and age can be negative (Copenheaver et al., 2011; D'Amato et al., 2013), we found a positive relationship between age and TRW in the model testing effects of restoration treatment on mean TRW during drought.

The larger TRW of residual trees compared to harvested trees in five of eleven decades during the common period provides a second line of support that the restoration treatment improved overall forest health and vigor. We found that residual trees had larger TRW, albeit not always significantly, beginning ca. 1930 (Figure 7) when the majority of trees were approximately 15 to 25 years old (Figure 6). At this age, the forest would be ending stem exclusion or beginning the understory re-initiation stage of development. Trees segregate into different crown positions during this time (Oliver, 1981), and these positions were mostly 
maintained until restoration treatment was implemented. Oaks selected as leave trees developed and maintained a healthy crown over the last 80 years that would have been visually discernable during residual tree selection in 2007 . One interesting finding is that residual trees had lower mean TRW than harvested trees in the 1900s, albeit not significantly (Figure 7). A previous study that found oaks with slow early growth had relatively fast growth later in life and were more likely to survive decline events caused by drought and insect infestations than trees with rapid early growth (Haavik et al. 2011). These results suggest that residual trees with slow early growth in this study may be less prone to succumb to oak decline.

Our third line of evidence indicating the restoration treatment improved overall forest health was that mean TRWs during the 1999 and 1986 droughts were larger for residual trees than harvested trees. Drought contributes to tree-ring decline and mortality (Jenkins and Pallardy, 1995; Voelker et al., 2008; Haavik et al., 2011), but our results indicate that selection for oaks with healthy and dominant crowns will mitigate for drought effects on oak decline. We did not find, however, that recovery after drought was better for residual trees than harvested trees. One explanation is that the identified droughts may not have been severe enough to impede growth of trees (even those with reduced growth during the drought) in years following drought. Oak trees can survive for decades through drought events before noticeable decline symptoms manifest (Pederson, 1998), and the relationship between drought and tree-ring growth is complex, affected by site conditions, tree density, and age (Jenkins and Pallardy, 1995; Voelker et al., 2008; Copenheaver et al., 2011). Additionally, dead trees were not sampled in our study, so TRW estimates for declining or unhealthy trees are underrepresented (Voelker et al., 2008). Factors we were unable to identify (e.g., frosts, fire, wind, ice storms) 
may have contributed to high growth variability during drought and recovery years. In fact, a late-season frost was documented in the region in 1986 during the 1986-1988 drought event (Liu and Muller, 1993). The larger TRW in residual trees overall and during drought events, however, suggests the restoration treatment may have improved resistance to stress, such as droughts, in the future (D'Amato et al., 2013).

Thinning or other silvicultural practices to promote growth of residual trees is a basic tenet of forest management. Increases in timber volume due to thinning or two-age shelterwood regeneration harvests are based on selecting trees with higher prior growth rates and dominant or co-dominant crown conditions (Gingrich, 1970), which are indicators of tree health. Well established silvicultural treatments, such as regeneration harvesting or thinning, should be appropriate to reach goals of improving forest health and restoring a stand to a desired structure, such as a woodland (Dey 2014). Our results indicate that restoration and traditional timber production objectives may be aligned when retention of residual trees is a primary goal, an important point in the practical application of restoration management (Stanturf et al. 2014b).

Implications for restoration

Much of eastern North America was severely impacted by large-scale destructive disturbances during European settlement (Ahern, 1933; Abrams, 1996). The forest landscape in this study was no exception, and we found evidence of a disturbance somewhere in these 610 ha stands every 3 years with large-scale disturbances occurring on a 24 year rotation. While some of these disturbances, particularly those occurring during stand initiation, would be considered agents of degradation (Stanturf et al., 2014a), improvements in forest health were 
achieved at forest maturity through removal of less vigorous trees identified by their crown condition and position (Schweitzer et al., 2014).

The stands might be more resilient to climate change, drought, pests, and pathogens due to the retention of legacy trees and trees with increased tree-ring growth following the restoration treatment (Noss, 2001; Millar et al., 2007). The health of residual trees is a measure of success of restoration or other silvicultural treatments (Anning and McCarthy 2013), and additional monitoring will be necessary to determine effectiveness of prescribed burning and to determine if forest health conditions and inciting factors change over time. Reducing stand density initially improved overall tree vigor, but desired drought response may decrease as stands age if stand density remains low (D'Amato et al., 2013). In our study, additional management may be necessary to remove trees that quickly recruited to the canopy (GONR trees), but may not yet be exhibiting decline symptoms in their crown morphology (Haavik et al., 2015).

Silviculturally, the oak woodland restoration treatment, at least in the early stages, is similar to a two-age shelterwood-burn regeneration method designed to increase the oak component of future stands (Brose, 2014). However, the shelterwood-burn method is focused primarily on oak recruitment into the canopy while the oak woodland treatment is focused primarily on residual tree health. With much focus on the oak regeneration problem in the last few decades (Dey et al., 2010; Arthur et al. 2012), our findings indicate that forest managers can use established silvicultural practices, such as two-age regeneration harvests, to improve overall health of residual trees while also regenerating the stand, particularly where long-lived species dominate. The stands in our study are currently experiencing an oak recruitment 
problem due to the high density of red maple and other large seedlings relative to oak (Schweitzer et al. 2014), as has been reported in throughout eastern North America (Dey et al., 2010; Brose et al., 2013). Recruitment of new regeneration in these stands may only be achieved by halting prescribed burning (Arthur et al., 2012). With proper residual tree management, this forest can endure decades of oak regeneration failure before treatments are implemented that successfully recruit the next cohort. This long-term management view is especially important during a time of impending threats from climate change, exotic pest species, and administrative constraints to management.

\section{Acknowledgements}

The authors would like to thank the following USDA Forest Service Southern and Northern Research Station employees for their help in field implementation: Ryan Sisk, Nathan Brown, David Feicht, Brian Simpson, and John Juracko. We thank David Loftis, Jeff Stringer, and the late Kurt Gottschalk for their contribution in initiating the overall study. The Daniel Boone National Forest staff was essential in establishment of this study, and we thank Dan Crockett, Mike Kluemke, Paul Finke, Leif Meadows, Robbie Sitzlar, Amos Stone, and David Taylor. Justin Hart, The University of Alabama, and Todd Hutchinson, USDA Forest Service, Northern Research Station, provided internal reviews that improved the manuscript. We are grateful to two anonymous reviewers that provided thoughtful comments that improved the manuscript.

\section{References}

Abrams, M.D., 1996. Distribution, historical development and ecophysiological attributes of oak species in the eastern United States. Ann Sci Forest 53, 487-512.

Ahern, G.P., 1933. Forest Bankruptcy in America. The Green Lamp League, Washington, D.C. 
Anning, A.K., and McCarthy, B.C., 2013. Competition, size and age affect tree growth response to fuel reduction treatments in mixed-oak forests of Ohio. For Ecol Manage 307, 74-83.

Anning, A.K., Dyer, J.M., and McCarthy, B.C., 2014. Tree growth response to fuel reduction treatments along a topographic moisture gradient in mixed-oak forests in Ohio, U.S.A. Can J For Res 44, 413-421.

Arthur, M.A., Alexander, H.D., Dey, D.C., Schweitzer, C.J., and Loftis, D.L., 2012. Refining the oak-fire hypothesis for management of oak-dominated forests of the eastern United States. J For 110, 255-266.

Arthur, M.A., Blankenship, B.A., Schörgendorfer, A., Loftis, D.L., and Alexander, H.D., 2015. Changes in stand structure and tree vigor with repeated prescribed fire in an Appalachian hardwood forest. For Ecol Manage 340, 46-61.

Brose, P.H., 2014. Development of prescribed fire as a silvicultural tool for the upland oak forests of the eastern United States. J For 112, 525-533.

Brose, P.H., Dey, D.C., Phillips, R.J., and Waldrop, T.A., 2013. A Meta-Analysis of the Fire-Oak Hypothesis: Does Prescribed Burning Promote Oak Reproduction in Eastern North America? For Sci 59, 322-334.

Buchanan, M.L., and Hart J.L., 2011. A Methodological Analysis of Canopy Disturbance Reconstructions Using Quercus alba. Can J For Res 41, 1359-1367.

Buchanan, M.L., and Hart J.L., 2012. Canopy disturbance history of old-growth Quercus alba sites in the eastern United States: Examination of long-term and broad-scale patterns. For Ecol Manage 267, 28-39. 
Clark, S.L., and Hallgren, S.W., 2004. Age estimation of Quercus marilandica and Quercus stellata: applications for interpreting stand dynamics. Can J For Res 34, 1353-1358.

Cook, E.R., Holmes, R.L., 1999. User's Manual for Program ARSTAN. University of Arizona, Tucsan, Arizona.

Copenheaver, C.A., Crawford C.J., and Fearer T.M., 2011. Age-specific responses to climate identified in the growth of Quercus alba. Trees 25, 647-653.

Crow, T.R., 2014. Functional restoration: from concept to practice. J Sustain For 33.sup1, S3S14.

D’Amato, A.W., Bradford, J.B., Fraver, S., and Palik, B.J. 2013. Effects of thinning on drought vulnerability and climate response in north temperate forest ecosystems. Ecolog App 23, 1735-1742.

Dey, D.C., 2014. Sustaining Oak Forests in Eastern North America: Regeneration and Recruitment, the Pillars of Sustainability. For Sci 60, 926-942.

Dey, D.C., Schweitzer, C.J. and Kabrick, J.M., 2016. Silviculture to restore oak woodlands. In Proceedings of the $18^{\text {th }}$ Biennial Southern Silvicultural Research Conference. USDA For Serv Gen Tech Rep, SRS-GTR-212, 160-169.

Dumroese, R.K., Palik B.J., and Stanturf, J.A., 2015. Forest Restoration is Forward Thinking. J For $113,1-2$.

Fralish, J.S., Franklin, S.B., and Close, D.D., 2000. Open woodland communities of southern Illinois, western Kentucky, and middle Tennessee. In Anderson, R.C., Fralish, J., and Baskin, J., eds, The savanna, barren, and rock outcrop communities of North America. Cambridge University Press, 171-189. 
Fritts, H.C., 1991. Reconstruction Large-Scale Climatic Patterns from Tree-ring Data. University of Arizona Press, Tuscan, Arizona.

Gingrich, S.F., 1970. Effects of density, thinning, and species composition on the growth and yield of eastern hardwoods. USDA For Serv Res Pap, NE-RP-144, 26-35.

Grissino-Mayer, H.D., 2001. Evaluating crossdating accuracy: a manual and tutorial for the computer program COFECHA. Tree-ring Res 57, 205-221.

Haavik, L.J., Billings, S.A., Guldin, J.M., and Stephen, F.M., 2015. Emergent insects, pathogens and drought shape changing patterns in oak decline in North America and Europe. For Ecol Manage 354, 190-205.

Haavik, L.J., Stahle, D.W., and Stephen, F.M., 2011. Temportal aspects of Quercus rubra decline and relationship to climate in the Ozark and Ouachita Mountains, Arkansas. Can J For Res $41,773-781$.

Hart, J.L., and Grissino-Mayer, H.D., 2008. Vegetation patterns and dendroecology of a mixed hardwood forest on the Cumberland Plateau: implications for stand development. For Ecol Manage 255, 1960-1975.

Hart, J.L., Austin, D.A., and van de Gevel, S.L. 2010. Radial Growth Responses of Three CoOccurring Species to Small Canopy Disturbances in a Secondary Hardwood Forest on the Cumberland Plateau, Tennessee. Phys Geo 31, 1-22.

Hart, J.L., Clark, S.L., Torreano, S.J., Buchanan, M.L., 2012. Composition, structure, and dendroecology of an old-growth Quercus forest on the tablelands of the Cumberland Plateau, USA. For Ecol Manage 266, 11-24. 
Hutchinson, T.F., Long, R.P., Ford, R.D., and Sutherland, E.K., 2008. Fire history and the establishment of oaks and maples in second-growth forests. Can J For Res 38, 1184-1198.

Hutchinson, T.F., Long, R.P., Rebbeck, J., Sutherland, E.K. and Yaussy, D.A., 2012. Repeated prescribed fires alter gap-phase regeneration in mixed-oak forests. Can J For Res 42, pp.303314.

Jenkins, M.A., and Pallardy, S.G. 1995. The influence of drought on red oak group species growth and mortality in the Missouri Ozarks. Can J F Res 25, 5369-5373

Keever, C., 1953. Present composition of some stands of the former oak-chestnut forest in the southern Blue Ridge Mountains. Ecology 34, 44-54.

Korstian, C.F., and Stickel, P.W. 1927. The natural replacement of blight-killed chestnut in the hardwood forests of the Northeast. US Government Printing Office, Washington, D.C.

Kozlowski, T.T. 1969. Tree physiology and forest pests. J For 67, 118-123.

Laatsch, J., and Anderson, R., 2000. An Evaluation of Oak Woodland Management in Northeastern Illinois, USA. Nat Areas J 20, 211-220.

LeBlanc, D., and Terrell, M. 1993. Comparison of growth-climate relationships between northern red oak and white oak across eastern North America. Can J For Res 41, 1936-1947. Liu, Y., and Muller, R.N., 1993. Effect of drought and frost on radial growth of overstory and understory stems in a deciduous forest. Am Midl Natur 129, 19-25.

Loftis, D.L., 1990. Predicting post-harvest performance of advance red oak reproduction in the Southern Appalachians. For Sci 36, 908-916.

Matlack, G.R., 2013. Reassessment of the Use of Fire as a Management Tool in Deciduous Forests of Eastern North America. Conserv Bio 27, 916-926. 
McElhinny, C., Gibbons, P., Brack, C., and Bauhus, J., 2005. Forest and woodland stand structural complexity: its definition and measurement. For Ecol Manage 218, 1-24.

McEwan, R.W., and McCarthy, B.C., 2008. Anthropogenic disturbance and the formation of oak savanna in central Kentucky, USA. J Biogeog 35, 965-975.

McEwan, R.W., Pederson, N., Cooper, A., Taylor, J., Watts, R., and Hruska, A., 2014. Fire and gap dynamics over 300 years in an old-growth temperate forest. Appl Veg Sci 17, 312-322.

McKeever, D.B., and Hatfield, C.A., 1984. Trends in the Production and Consumption of Major Forest Products in the United States. USDA For Serv Res Bull FPL-RB-14A.

Millar, C.I., Stephenson, N.L., and Stephens, S.L., 2007. Climate Change and Forests of the Future: Managing in the Face of Uncertainty. Ecol Appl 17, 2145-2151.

National Oceanic and Atmospheric Administration: National Centers for Environmental Information. 2015. Climate Data Online. <http://www.ncdc.noaa.gov/cdo-web/> Noss, R.F., 2001. Beyond Kyoto: forest management in a time of rapid climate change. Conserv Bio 15, 578-590.

Nowacki, G.J., Abrams, M.D., and Lorimer, C.G., 1990. Composition, structure, and historical development of northern red oak stands along an edaphic gradient in north-central Wisconsin. For Sci 36, 276-292.

Nowacki, G.J., and Abrams, M.D., 1997. Radial-growth averaging criteria for reconstructing disturbance histories from presettlement-origin oaks. Ecol Mono 225-249.

Oliver, C.D., 1981. Forest development in North America following major disturbances. For Ecol Manage 3, 153-168. 
Pach, M., and Podlaski, R., 2015. Tree diamater structural diversity in Central European forests with Abies alba and Fagus sylvatica: managed versus unmanaged forest stands. Ecol Res 30, 367-384.

Palmer, W.C., 1965. Meteorological drought. Research Paper 45, U.S. Department of Commerce, Weather Bureau, Washington, DC.

Pederson, B.S., 1998. The role of stress in the mortality of Midwestern oaks as indicated by growth prior to death. Ecology 71, 79-93.

Pielou, E.C., 1966. The measurement of diversity of different types of biological collections. J Theor Biol 13: 131-144

Rentch, J.S., Desta, F., and Miller, G.W., 2002. Climate, canopy disturbance, and radial growth averaging in a second-growth mixed-oak forest in West Virginia, U.S.A. Can J For Res 32, 915-927.

Rentch, J.S., Fajvan, M.A., and Hicks, R.R., Jr. 2003. Oak establishment and canopy accession strategies in five old-growth stands in the central hardwood forest region. For Ecol Manage $184,285-297$.

Roche, L., Rice, K., and Tate, K., 2012. Oak conservation maintains native grass stands in an oak woodland-annual grassland system. Biodiv Conserv 21, 2555-2568.

Royse, J., Arthur, M.A., Schorgendorfer, A., and Loftis, D.L., 2010. Establishment and growth of oak (Quercus alba, Quercus prinus) seedlings in burned and fire-excluded upland forests on the Cumberland Plateau. For Ecol Manage 260, 502-510.

Ryan, K.C., Knapp E.E., and Varner, J.M., 2013. Prescribed fire in North American forests and woodlands: history, current practice, and challenges. Front Ecol Environ 11, e15-e23. 
SAS Institute, 2012. SAS/STAT 12.3 User's Guide. Cary, North Carolina, USA.

Schaich, H., Kizos, T., Schneider, S., and Plieninger, T., 2015. Land change in eastern Mediterranean wood-pasture landscapes: the case of deciduous oak woodlands in Lesvos (Greece). Environ Manage 56, 110-126.

Schweitzer, C.J., Clark, S.L., Gottschalk, K.W., Stringer, J., and Sitzlar, R., 2014. Proactive restoration: planning, implementation, and early results of silvicultural strategies for increasing resilience against gypsy moth infestation in upland oak forests on the Daniel Boone National Forest, Kentucky. J For 112, 401-411.

Selvi, F., and Valleri, M., 2012. Cork oak woodlands in the north Tyrrhenian area (Italy): distribution and plant species diversity of a relict forest ecosystem. Biodivers Conserv 21, 3061-3078.

Shannon, C.E., and Weaver, W., 1949. The Mathematical Theory of Communications. University of Illinois Press, Urbana.

Stanturf, J.A., 2015. Future landscapes: opportunities and challenges. New For 46, 615-644.

Stanturf, J.A., Palik, B.J., Williams, M.I., Dumroese, R.K., and Madsen, P., 2014a. Forest Restoration Paradigms. J Sustain For 33, S161-S194.

Stanturf, J.A., Palik, B.J., and Dumroese, R.K., 2014b. Contemporary forest restoration: A review emphasizing function. For Ecol Manage 331, 292-323.

Stokes, M.A., and Smiley, T.L., 1996. An Introduction to Tree-ring Dating. The University of Arizona Press, Tucson.

USDA Forest Service, 2004a. Land and Resource Management Plan for the Daniel Boone National Forest. Management Bulletin R8-MB 117A. 
USDA Forest Service, 2004b. Land and Resource Management Plan Jefferson National Forest. Management Bulletin R8-MB 115A.

USDA Forest Service, 2004c. Land and Resource Management Plan Cherokee National Forest. Management Bulletin R8-MB 114A

Vander Yacht, A.L., 2013. Vegetation Response to Oak Savanna and Woodland Restoration in the Mid-South USA. Master's Thesis, University of Tennessee, <http://trace.tennessee.edu/utk_gradthes/1690>

Voelker, S.L., Muzika, R., and Guyette, R.P., 2008. Individual Tree and Stand Level Influences on the Growth, Vigor, and Decline of Red Oaks in the Ozarks. For Sci 54, 8-20. 

Table 1. Threshold values (percent change in 10-year running mean) for detection of minor and major releases.

\begin{tabular}{llll}
\hline & $\begin{array}{l}\text { Number of annual } \\
\text { rings }\end{array}$ & $\begin{array}{l}\text { Percent growth } \\
\text { change value for }\end{array}$ & $\begin{array}{l}\text { Percent growth } \\
\text { change value for }\end{array}$ \\
Age (years) & minor release & major release \\
\hline $1-100$ & 4568 & $35-71$ & $\geq 72$ \\
$101-150$ & 382 & $34-67$ & $\geq 68$ \\
$151-200$ & 237 & $29-57$ & $\geq 58$ \\
$201-250$ & 158 & $19-37$ & $\geq 20$ \\
\hline
\end{tabular}


Table 2. Percent of average early summer (May-July) precipitation and average early summer PDSI for four drought events and associated recovery periods.

\begin{tabular}{|c|c|c|}
\hline $\begin{array}{l}\text { Drought (D) or } \\
\text { recovery }(R) \text { yea }\end{array}$ & Precipitation & PDSI \\
\hline 1964-1966 (D) & 68 & -1.53 \\
\hline $1967-1968(R)$ & 108 & +0.86 \\
\hline 1969-1970 (D) & 61 & -1.80 \\
\hline $1971-1972(R)$ & 131 & +1.89 \\
\hline 1986-1988 (D) & 73 & -2.82 \\
\hline 1989-1991 (R) & 107 & +2.48 \\
\hline 1999-2000 (D) & 79 & -2.54 \\
\hline 2001-2002 (R) & 110 & +0.49 \\
\hline
\end{tabular}


Table 3. Statistics for release events. A release initiation is the first year of a release event that lasted at least 3 years.

\begin{tabular}{|c|c|c|c|}
\hline & All & Major & Minor \\
\hline Number of release events recorded across all trees & 116 & 55 & 61 \\
\hline Number of unique release initiation years & 59 & 36 & 41 \\
\hline Number of unique release years & 142 & 116 & 124 \\
\hline Percent of trees recording a release & 76 & 46 & 44 \\
\hline Percent of years recording a release initiation year & 26 & 16 & 18 \\
\hline Percent of years recording a release year & 63 & 51 & 55 \\
\hline Mean release initiation return interval (years) & 3.2 & 4.7 & 4.7 \\
\hline Std dev & 5.2 & 8.6 & 6.6 \\
\hline Weibull median & 2.0 & 2.3 & 2.8 \\
\hline Mean release length (years) & 9.9 & 12.7 & 6.7 \\
\hline Std dev & 4.8 & 3.9 & 3.3 \\
\hline Median & 9 & 12 & 6 \\
\hline Mean number of releases per tree & 1.1 & 0.5 & 0.6 \\
\hline Std dev & 1.0 & 0.8 & 0.8 \\
\hline Median & 1 & 0 & 0 \\
\hline Mean return interval for large-scale releases & 23.7 & -- & -- \\
\hline Std dev & 19.0 & -- & -- \\
\hline Weibull median & 20.3 & -- & -- \\
\hline
\end{tabular}


Table 6. Analysis of variance for effects of restoration treatment on mean tree-ring width (TRW) and percent growth change in TRW during recovery period for each drought event and for all drought events combined.

\begin{tabular}{lllll}
\hline Drought event & Mean TRW during drought & \multicolumn{2}{l}{ Percent growth change in TRW } \\
& & & from drought to recovery period \\
& F & P & F & 0.4831 \\
\hline 1964 & 3.30 & 0.1291 & 0.57 & 0.8060 \\
1969 & 4.61 & 0.0845 & 0.07 & 0.4062 \\
1986 & 6.26 & 0.0543 & 0.70 & 0.8683 \\
1999 & 13.27 & 0.0149 & 0.03 & 0.7944 \\
Combined & 4.85 & 0.0789 & 0.08 & \\
\hline
\end{tabular}


Figure 1. Recruitment dates (pith date) of trees that recruited in gaps (A) (GO) or in the understory (B) (UO), and had either no subsequent releases (NR) or additional release (GR).
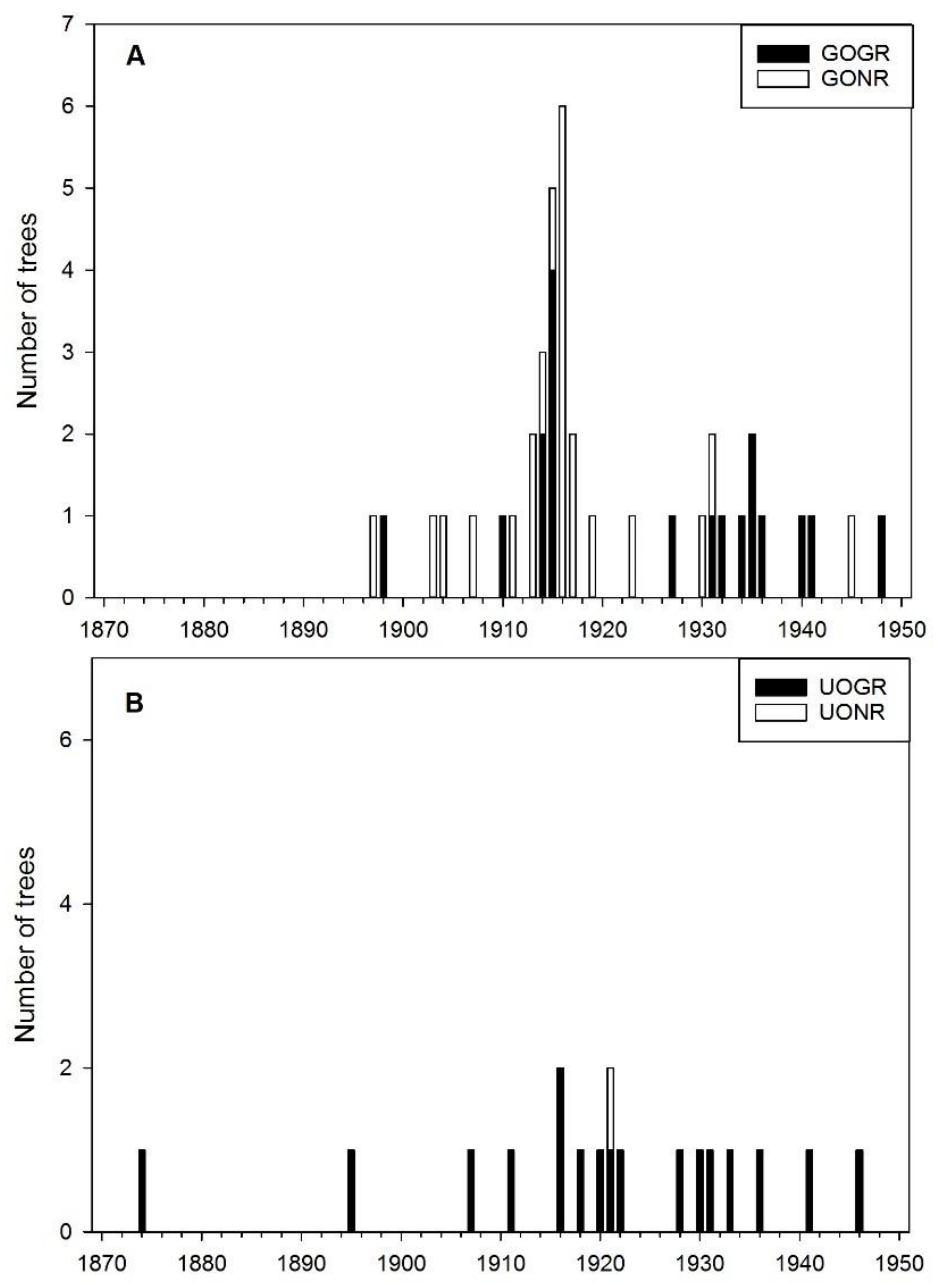
Figure 2. Chronology (1771-1996) of major (A) and minor (B) release initiations by stand. Dark vertical bars indicate release initiations. A composite chronology is shown across the bottom of each graph.
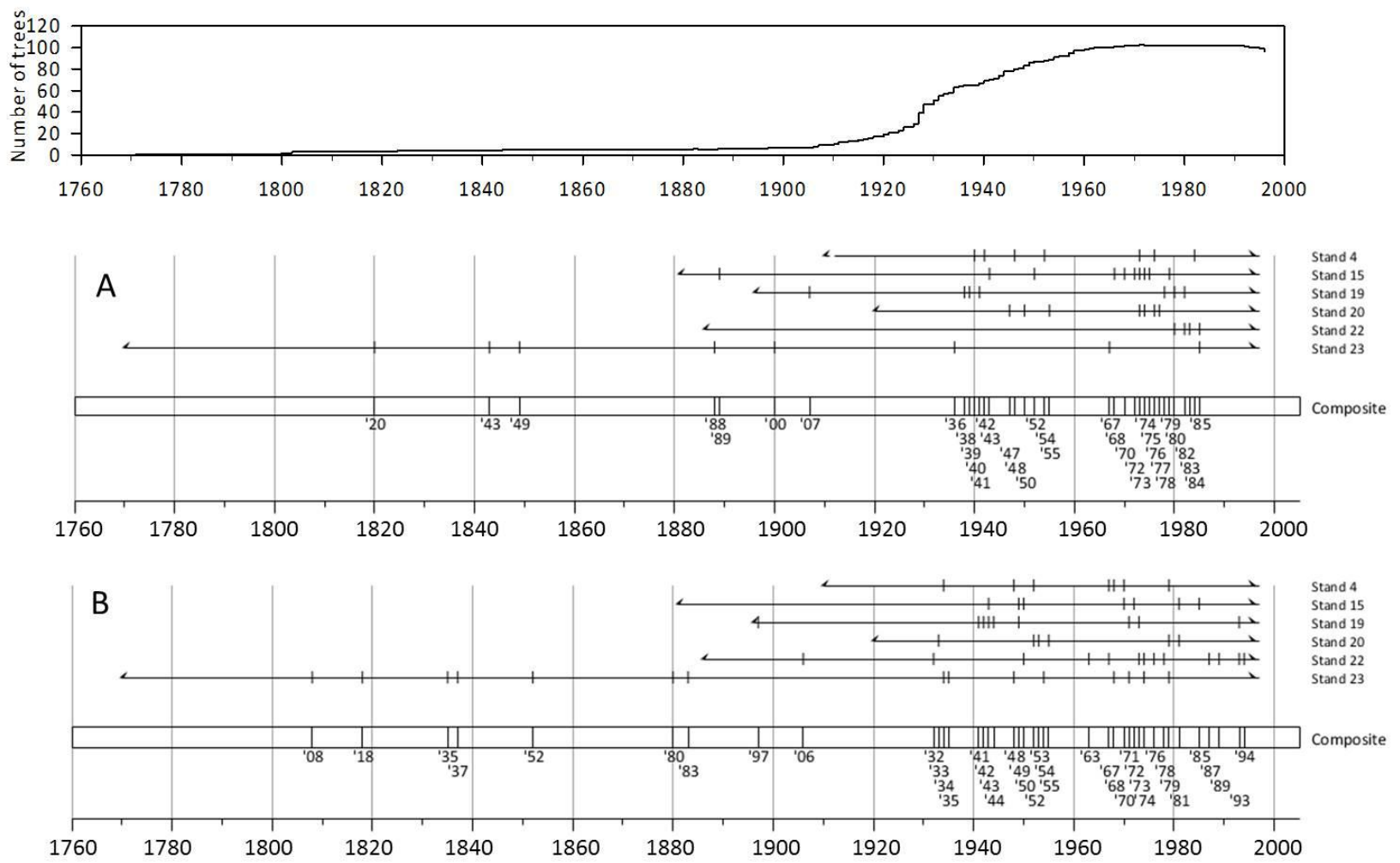
Figure 3. Chronology (1771-1996) of all release years by stand. Dark vertical bars indicate release initiations. A composite chronology is shown across the bottom. Solid vertical bars extending through all stands indicate large-scale releases.

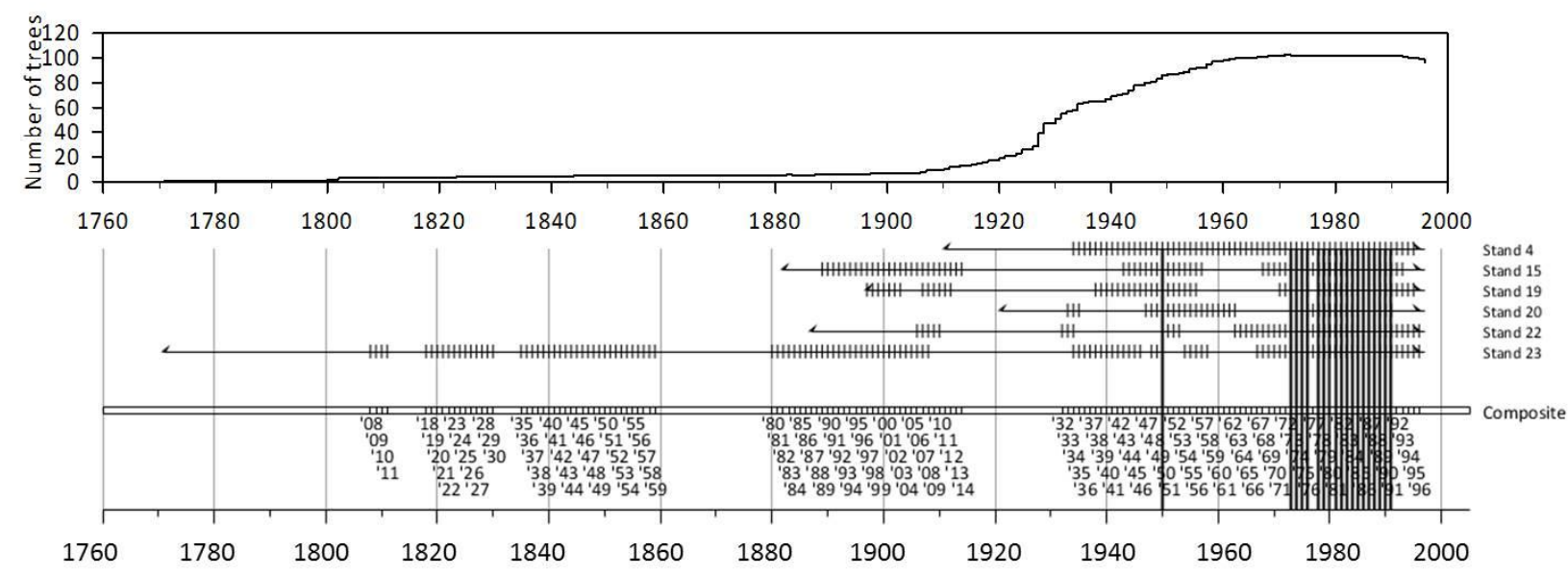


Figure 4. Release index chronology (number of releases divided by maximum sample size by decade).

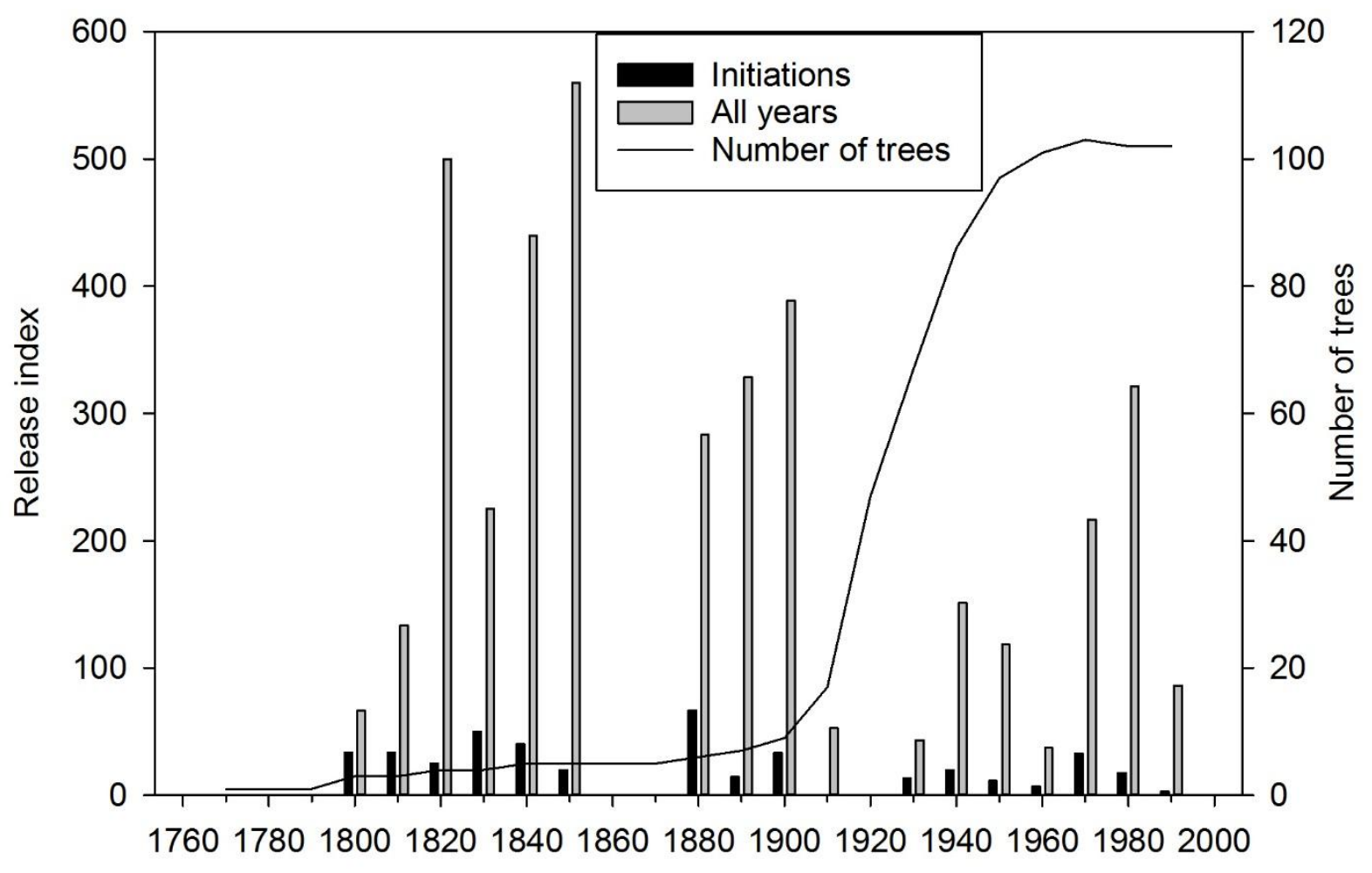


Figure 5. Diameter at breast height (DBH) distributions for stands before and after an oak woodland restoration treatment.

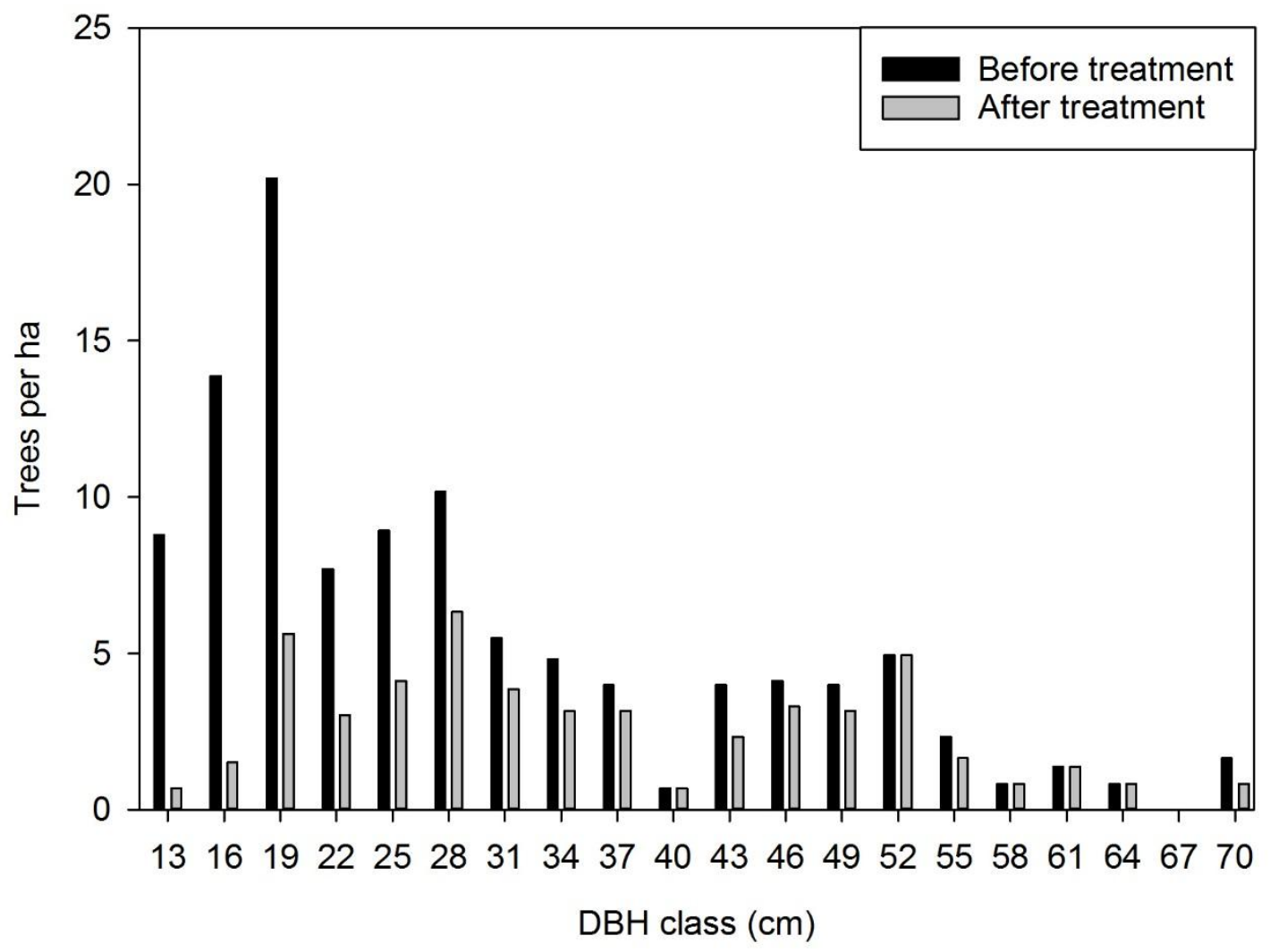


Figure 6. Age distributions for stands before and after an oak woodland restoration treatment.

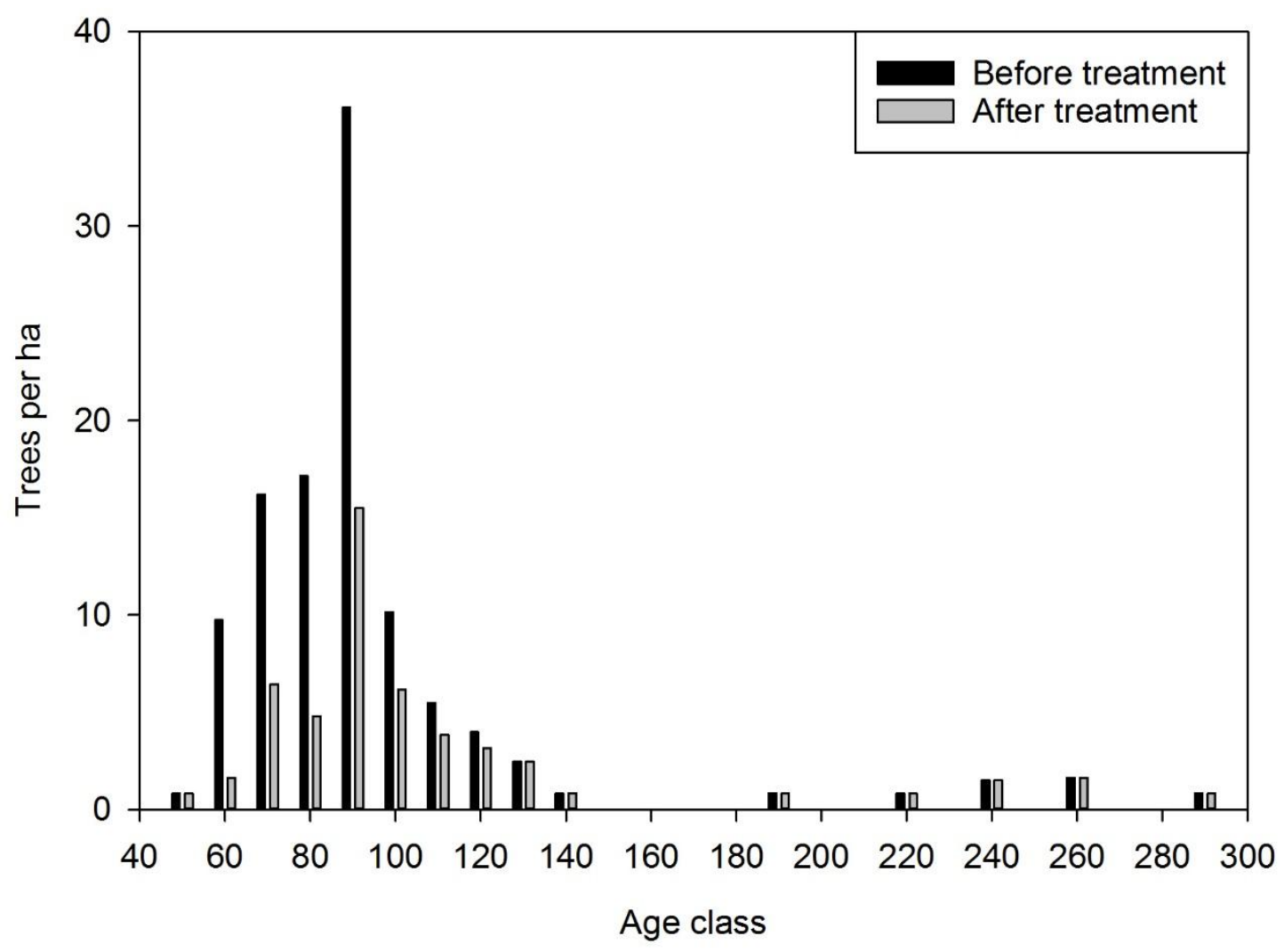


Figure 7. Decadal least-squares means of tree-ring widths (TRW) for harvested and residual trees in an oak woodland restoration treatment. Decades with asterisks indicate significant differences $(P<0.05)$ between harvested and residual trees.

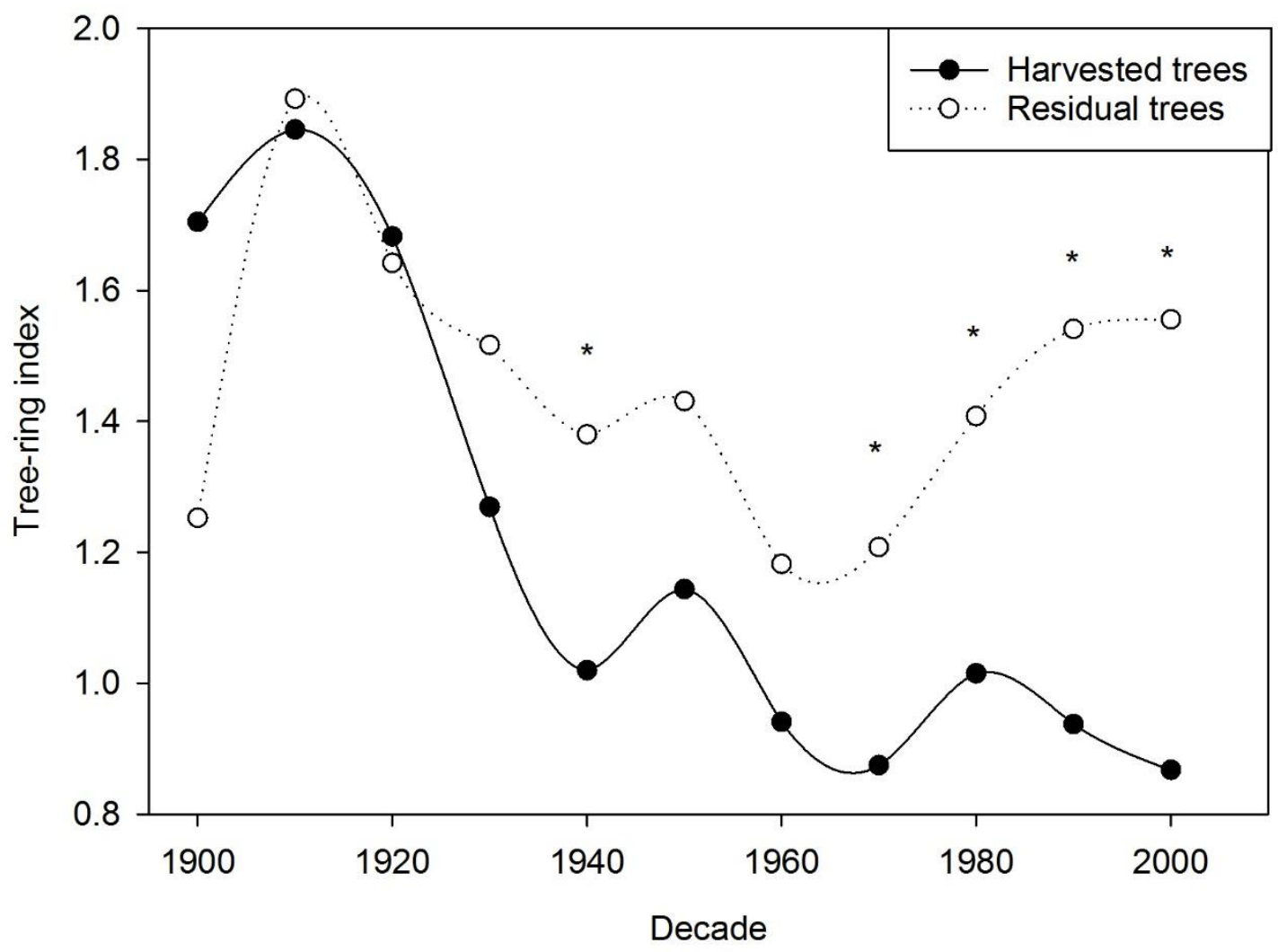

